Volume 10. Nomor 1. June 2015

\title{
Peran Rumah Detensi Imigrasi dalam Perlindungan Hak Asasi Manusia Pencari Suaka
}

\author{
Villian Febri Morradi $\bowtie$
}

Fakultas Hukum Universitas Negeri Semarang, Indonesia

Permalink/DOI http://dx.doi.org/10.15294/pandecta.v9i1.

\begin{tabular}{l} 
Info Artikel \\
\hline Sejarah Artikel: \\
Diterima October 2014 \\
Disetujui December 2014 \\
Dipublikasikan January 2015 \\
\hline Keywords: \\
Asylum Seekers; \\
Immigration Detention Center \\
Semarang
\end{tabular}

Abstrak

Mobilitas orang asing di Indonesia sangat banyak dan bermacam-macam. Salah satunya adalah pencari suaka yang masuk ke Indonesia tanpa dokumen keimigrasian. Dalam penanganan pelanggaran keimigrasian dan untuk menampung para pencari suaka tersebut maka dibentuklah Rumah Detensi Imigrasi guna memberikan pemenuhan hak asasi manusia bagi mereka. Penelitian ini bertujuan untuk mengetahui dan menganalisis Rumah Detensi Imigrasi Semarang dalam pemenuhan HAM bagi para Pencari Suaka dan untuk mengetahui dan menganalisis faktor pendukung dan penghambat yang dihadapi. Jenis penelitian ini menggunakan Yuridis Sosiologis dan analisis data menggunakan metode pendekatan kualitatif. Data penelitian diperoleh melalui wawancara dan dokumentasi. Sedangkan proses pengolahan data melalui pengumpulan data, penyajian data, analisis data, dan kesimpulan. Rumah Detensi Imigrasi Semarang sendiri dalam pemenuhan HAM bagi para pencari suaka dilakukan dengan cara memberikan program-program yang dilaksanakan secara terstuktur yaitu pelayanan cek kesehatan, memberikan kebutuhan makanan dan memberikan akses pendidikan bagi para pencari suaka. Faktor Pendukungnya adalah Rumah Detensi Imigrasi Semarang bekerjasama dengan pihak-pihak terkait yaitu PKBI dan Rumah Sakit guna memberikan pemenuhan HAM pencari suaka dan antusias dari para pencari suaka yang selalu ikut berpartisipasi dalam program dan kegiatan yang diberikan. Adapun faktor penghambatnya yaitu tidak adanya tenaga medis yang standby 24 jam, tidak tersedianya gudang penyimpanan obat-obatan, dan faktor bahasa yang digunakan dalam komunikasi serta selera menu makanan yang berbeda-beda setiap deteni disana.

\begin{abstract}
Mobility of foreigners in Indonesia are many and diverse. One is the asylum seekers who enter Indonesia without immigration documents. In the handling of immigration violations and to accommodate asylum seekers immigration detention center will be established in order to provide fulfillment of human rights for them. This study aims to identify and analyze the immigration detention center in Semarang in the fulfillment of human rights for asylum seekers and to determine and analyze the supporting factors and obstacles encountered. This research uses Juridical Sociological and analyzed using qualitative approach. Data were obtained through interviews and documentation. While the data processing through data collection, presentation of data, data analysis, and conclusions. Semarang immigration detention center in the fulfillment of human rights for asylum seekers is done by providing programs that are implemented in a structured namely health check services, provide food needs and provide access to education for asylum seekers. Supporters factor is immigration detention center in Semarang in cooperation with the relevant parties, namely PKBI and the Hospital to provide fulfillment of human rights of asylum seekers and the enthusiasm of the asylum seekers who have always participated in the programs and activities provided. The inhibiting factor is the lack of medical personnel 24 hours standby, unavailability of medicines storage sheds, and factor the language used in communications and taste the food menu is different every deteni there.
\end{abstract}

$\triangle$ Alamat korespondensi:

Gedung K1 Sekaran, Gunungpati, Semarang

E-mail: villianfebri18@gmail.com
(C) 2015 Universitas Negeri Semarang ISSN 1907-8919 (Cetak) ISSN 2337-5418 (Online) 


\section{Pendahuluan}

Sebagaimana kita ketahui, "negara Indonesia memiliki kondisi geografis yang sangat khas. Indonesia memiliki wilayah daratan yang berbentuk gugusan-gugusan pulau sebanyak 17.508 pulau-pulau. Terbentang dari Sabang hingga Merauke dan dipisahkan oleh laut-laut di antara pulau-pulaunya. Sebagai negara kepulauan, Indonesia diuntungkan memiliki tiga jenis wilayah yaitu wilayah darat, laut dan udara yang mungkin tidak semua negara memilikinya" (Arifin, 2014: 2).

Kondisi geografis seperti itu memiliki potensi sekaligus kelemahan. Potensi terbesarnya adalah sumber daya yang ada di dalamnya, sedangkan kelemahannya adalah masalah perhubungan antar pulau-pulau serta masalah keamanan dan kedaulatan. Namun untuk mewujudkan Negara Kesatuan Republik Indonesia yang utuh dan menyatu, pada tanggal 13 Desember 1957, Perdana Menteri Ir. Djoeanda, mendeklarasikan kepada dunia bahwa laut Indonesia adalah termasuk laut di sekitar, di antara, dan di dalam kepulauan Indonesia, yang dikenal sebagai "DEKLARASI DJOEANDA". Perjuangan-perjuangan Indonesia di dunia internasional membawa hasil yang memuaskan dengan diakuinya dan diterimanya konsep negara kepulauan serta perairan pedalaman/ perairan kepulauan. Predikat sebagai negara kepulauan tidak hanya menambah hak-hak negara atas perairan, pedalaman sebagai laut wilayahnya, namun di dalamnya juga terdapat berbagai kewajiban-kewajiban internasional yang harus dipenuhi oleh Indonesia (Arifin, 2014: 2).

Negara Indonesia adalah negara yang memiliki posisi strategis dalam pergaulan internasional, baik dari geografis maupun potensi sumber daya alam dan sumber daya manusia yang mengakibatkan arus lalu lintas orang masuk dan keluar wilayah Indonesia semakin meningkat dan mudah untuk di akses. Semakin terbuka lebarnya jalur lalu lintas antar negara pada saat ini menyebabkan meningkatnya pula mobilitas barang dan manusia antar satu negara ke negara lain. Dalam memenuhi kebutuhannya, secara tidak langsung negara membuka lebar pintu masuk dan akses ke dalam ruang lingkup batasan negara. Masing-masing individu juga dengan mudah melakukan perjalanan dari satu negara ke negara lain dengan berbagai kepentingan (Safriady, 2014: 1).

Fenomena seperti ini, berbagai usaha dilakukan untuk tetap menjaga stabilitas negara. Menurut Sulhan, Kepala Sub Seksi Keamanan di Rumah Detensi Imigrasi Semarang, menyatakan bahwa:

\begin{abstract}
"Salah satu pelanggaran yang dapat mengganggu kestabilan negara di antarnya yaitu banyak terjadinya pelanggaran izin keimigrasian oleh warga negara asing yang tidak sesuai dengan prosedur yang diatur dalam Undang-Undang Nomor 6 Tahun 2011 tentang Keimigrasian. Selain pelanggaran izin keimigrasian juga masuknya para pencari suaka ke wilayah Indonesia dengan berbagai kepentingan (Wawancara, 12 November 2014 pukul 10.00 WIB)".
\end{abstract}

Dalam penanganan pelanggaran keimigrasian dan untuk menampung para pencari suaka tersebut maka dibentuklah Rumah Detensi Imigrasi yang bertujuan untuk menangani pelanggaran prosedural keimigrasian yang dilakukan oleh warga negara asing termasuk para pencari suaka, dan juga melindungi hak asasi manusia dari warga negara asing sehingga dengan demikian maka dampak dari pelanggaran prosedural yang dilakukan oleh warga negara asing dapat di netralisir melalui Rumah Detensi Imigrasi sekaligus melindungi hak asasi manusia warga negara asing yang berada di wilayah Negara Republik Indonesia.

Langkah pengawasan terhadap warga negara asing di Indonesia pada dasarnya juga diikuti dengan penegakan hukum yang cepat dan tepat atas setiap pelanggaran keimigrasian dengan cara koordinasi pengawasan orang asing dilakukan secara terpadu, dan siporadik dibentuk di tingkat pusat, di tingkat Propinsi dan di tingkat daerah. Menurut Wilis (2009: 132), mekanisme pelaksanaan penegakan hukum terhadap orang asing harus dilakukan dengan mengadakan koordinasi dengan badan atau instansi pemerintah yang di bidang tugas meyangkut orang asing, badan atau instansi tersebut antara lain Ke- 
menterian Luar Negeri, Kementerian Dalam Negeri, Kementerian Pertahanan Keamanan, Kementerian Tenaga Kerja, Kejaksaan Agung, Badan Intelijen Negara, dan Kepolisisan Negara Republik Indonesia. Dengan adanya permasalahan seperti ini di Indonesia, pemerintah Indonesia membuat regulasi yaitu Undang-Undang Nomor 6 tahun 2011 tentang Keimigrasian. Kebijakan pemerintah ini dalam mengatur berbagai macam warga negara asing keluar dan masuk ke wilayah Indonesia menganut pinsip selective policy yaitu suatu kebijakan berdasarkan prinsip selektif.

Berdasarkan prinsip yang dikemukakan oleh Willis (2009: 132), hanya orang-orang asing yang dapat memberikan manfaat bagi kesejahteraan rakyat, bangsa dan Negara Republik Indonesia, yang tidak membahayakan keamanan dan ketertiban serta tidak bermusuhan baik terhadap rakyat maupun Negara Kesatuan Republik Indonesia yang berdasarkan Pancasila dan Undang-Undang Dasar 1945 (UUD 1945), yang diizinkan masuk atau keluar wilayah Indonesia, dan untuk itu perlu ada pengaturan dan batasan berupa perizinan yang diberian kepada orang asing apabila hendak tinggal di Indonesia.

Sebelumnya telah ada penelitian terkait dengan pengawasan orang asing di Indonesia yang dilakukan oleh Faizal (2013: 90) yang menyimpulkan bahwa Peran dan fungsi Kantor Wilayah Kementrian Hukum dan HAM Jawa Tengah dalam pelaksanaan pengawasan dan penindakan keimigrasian terhadap orang asing yaitu sebagai (a) koordinator dalam pengkoordinasian, perencanaan, pengendalian program kegiatan pengawasan dan penindakan keimigrasian terhadap orang asing; (b) Pembina kegiatan pengawasan dan penindakan keimigrasian terhadap orang asing; dan (c) Penegak hukum di bidang keimigrasian. Adapun kendala Kantor Wilayah Kementerian Hukum dan HAM Jawa Tengah dalam melaksanakan pengawasan dan penindakan keimigrasian terhadap orang asing diantaranya yaitu : (a) Kurangnya kualitas dan kuantitas sumber daya manusia pegawai Kantor Wilayah Kementerian Hukum dan HAM Jawa Tengah dan jajaran unit pelaksana teknis; dan (b) Anggaran kerja untuk kegiatan pengawasan dan penindakan orang asing tidak aplikatif dengan rencana kerja (Faizal, 2013: 90).

Namun demikian, meskipun warga negara asing telah melakukan pelanggaran secara yuridis mengenai keimigrasian tetapi para warga negara asing tersebut tidak dapat diperlakukan sewenang-wenang oleh pemerintah negara Indonesia karena bagaimanapun juga warga negara asing memiliki hak asasi sebagai manusia yang sama dengan warga negara Indonesia. Warga negara asing yang berada di Rumah Detensi Imigrasi juga memiliki hak-hak yang wajib dilindungi dan dipenuhi. Hak-hak tersebut diantaranya hak atas pendidikan, hak atas kesehatan dan hak atas makanan yang layak menurut Pasal 15 Peraturan Direktur Jendral Imigrasi Nomor F-1002.PR.02.10 Tahun 2006 tentang Tata Cara Pendetensian Orang Asing.

Mengenai pelanggaran hukum Indonesia yang dilakukan oleh warga negara asing, telah dilakukan penelitian oleh Mulhadi (2014: 55), yang menyimpulkan bahwa: Perlindungan internasional terhadap pengugsi diatur dalam Konvensi 1951 dan Protokol 1967. Dalam Kovesi 1951 dan Protokol 1967 terdapat ketentuan yang berisikan apa yang menjadi hak-hak dan kewajiban para pengungsi seperti hak untuk tidak dipulangkan ke negara asalnya. Selain mendapatkan hak-haknya, pengungsi juga dibebankan beberapa kewajiban seperti menghormati dan mematuhi hukum yang berlaku di negara ia berada dan kewajiban membayar pajak dan biaya-biaya fiskal lainnya (Mulhadi, 2014: 55).

Dalam menangani pengungsi dan pencari suaka yang berada di Indonesia menurut Mulhadi, diperlukan kerjasama internasional yang menangani imigran atau berhubungan dengannya, seperti Komisi PBB untuk Urusan Pengungsi (UNHCR), Organisasi Internasional yang Mengungsi Migran (IOM) juga sangat penting. Konsep perlindungan yang diberikan oleh UNHCR adalah lebih menekankan pada usaha pengembangan instrumen hukum internasional untuk kepentingan para pengungsi dan memastikan agar mereka mendapat perlakuan sesuai dengan ketentuan instrumen hukum internasional, khususnya yang bekaitan dengan hak untuk bekerja, 
jaminan sosial, serta hak untuk mendapatkan atau memanfaatkan fasilitas perjalanan. Sedangkan peran IOM dalam menangani pengungsi dan pencari suaka di Indonesia adalah mengurus dan menjamin kehidupan para pengungsi dan pencari suaka dengan memberikan tempat penampungan (rudenim) (Mulhadi, 2014: 55).

\section{Metode Penelitian}

Pendekatan penelitian kualitatif hukum dengan jenis penelitian yuridis sosiologis (Amiruddin, 2012). Lokasi penelitian di Rumah Detensi Imigrasi Semarang. Analisis data secara deskriptif. Fokus penelitian pada Rumah Detensi Imigrasi Semarang dalam perlindungan hak asasi manusia pencari suaka dan faktor pendukung dan penghambatnya. Sumber data meliputi data primer dan sekunder yang diambil dengan menggunakan metode wawancara dan dokumentasi. Teknik analisis data yang digunakan yaitu penelitian hukum sosiologis. Penelitian ini dilakukan dengan mengkaji bahan-bahan hukum sekaligus juga mengidentifikasikan berbagai peraturan yang berkaitan dengan Rumah Detensi Imigrasi dalam Perlindungan Hak Asasi Manusia Warga Negara Asing yang dikaitkan dengan bagaimana penerapan aturan hukum tersebut di masyarakakat. Analisis mengenai permasalahan yang diangkat dalam penelitian ini, dilakukan dengan cara menganalisis permasalahan yang ada di lapangan yakni mengenai perlindungan hak asasi manusia, selanjutnya akan dikaji dengan dikaitkan dengan peraruran perundang-undangan yang berlaku. Setelah analisis data selesai, maka hasilnya akan disajikan secara deskriptif, yaitu dengan menuturkan dan menggambarkan apa adanya sesuai dengan permasalahan yang diteliti. Dari hasil tersebut kemudian ditarik kesimpulan yang merupakan jawaban atas permasalahan yang diangkat dalam penelitian ini (Amiruddin, 2012).

\section{Hasil Penelitian dan Pembahasan}

\section{a. Rumah Detensi Imigrasi Semarang dalam Perlindungan HAM Pencari Sua- ka}

Pemenuhan hak untuk mendapatkan Pendidi-

\section{kan bagi anak-anak}

Deklarasi Universal Hak Asasi Manusia (DUHAM) merupakan langkah besar yang diambil oleh masyarakat internasional pada tahun 1948. Norma-norma yang terdapat dalam DUHAM merupakan norma internasional yang disepakati dan diterima oleh negara-negara di dunia melalui Perserikatan Bangsa-Bangsa. DUHAM merupakan kerangka tujuan HAM yang dirancang dalam bentuk umum dan merupakan sumber utama pembentukan dua instrumen HAM, yaitu: Kovenan Internasional tentang Hak Sipil dan Politik serta Kovenan Internasional tentang Hak Ekonomi, Sosial dan Budaya (Kusumaatmadja, 2003: 18).

Hak atas pendidikan sendiri telah diatur dalam Deklarasi Universal HAM (Universal Declaration of Human Rights) Pasal 1 yang menyebutkan bahwa setiap orang berhak mendapatkan pendidikan. Tak terkecuali para pencari suaka khususnya anak-anak yang berada di negara lain.

Perlindungan terhadap pengungsi anak merupakan salah satu kategori pengungsi yang memerlukan perlindungan khusus yang diatur menurut Konvensi Hak-hak anak 1989. Dalam Pasal 22 konvensi anak berisi bahwa kewajiban negara untuk mengeluarkan kebijakan yang bertujuan untuk menjamin dan memberikan perlindungan kepada pengungsi anak agar memperoleh hak-haknya yang tepat dan sesuai dengan harkat kemanusiaan. Pemberian perlindungan terhadap pengungsi anak didasarkan pada hukum internasional maupun hukum nasional negara asal. Dalam rangka memberikan perhatian dan perlindungan secara serius terhadap pengungsi anakanak, didukung pula konvensi hak anak-anak (Convention on the Rights of the Child). Konvensi ini terdiri atas 54 pasal dan memuat kewajiban negara-negara suaka untuk memberikan perlindungan terhadap anak. Dalam konvensi ini terdapat empat prinsip yang harus ditaati dan dihormati oleh setiap Negara suaka yaitu :

a) Prinsip non-diskriminasi anak, dimana anak-anak dapat menikmati hakhak mereka dalam bentuk apa pun tanpa memandang ras, warna kulit, jenis kelamin, bahasa, agama, pen- 
dapat politik atau pendapat lainnya, kewarganegaraan, asal usul kebangsaan atau sosial, kekayaan, kecacatan, kelahiran atau status lain yang tercantum dalam Pasal 2 ayat (1) konvensi hak anak-anak.

b) Kepentingan terbaik bagi anak, yang dirumuskan dalam Pasal 3 yaitu jika penguasa mempengaruhi anak-anak, pertimbangan pertama haruslah didasarkan pada kepentingan yang terbaik bagi anak. Prinsip ini berkenaan dengan keputusan pengadilan, pejabat administratif, badan-badan legislatif dan juga lembaga-lembaga kesejahteraan sosial pemerintah maupun swasta.

c) Hak untuk hidup dan mengembangkan diri, diatur dalam Pasal 6 yang mencakup rumusan mengenai hak untuk bertahan dan mengembangkan diri (baik jasmani maupun mental, emosional dan sosial) yang harus dijamin semaksimal mungkin.

d) Pandangan anak yang diatur dalam Pasal 12. Prinsip ini menekankan bahwa anak-anak yang mampu mengeluarkan dan mampu untuk menyampaikan pendapat sacara bebas, dan selain itu juga dalam hak untuk didengar.

Dalam konvensi ini, hak-hak anak meliputi (Romsan, 2003: 178):

1. Setiap anak memiliki hak yang melekat pada dirinya untuk hidup, dan semua Negara harus menjamin sebesar-besarnya perkembangan diri dari kelangsungan hidup anak

2. Setiap anak memiliki hak atas sebuah nama dan kewarganegaraan sejak kelahirannya

3. Anak-anak tidak boleh dipisahkan dari orangtua mereka, kecuali oleh pejabat yang berwenang bagi kebaikan anak-anak tersebut

4. Negara-negara suaka harus membantu pertemuan atau penyatuan kembali keluarga-keluarga dengan memperkenankan keluar masuknya orangorang dari atau ke wilayah mereka

5. Para orang tua memiliki tanggung- jawab utama untuk membesarkan anak mereka, akan tetapi Negara harus memberikan bantuan yang layak dan mengembangkan lembaga-lembaga perawatan anak

6. Negara-negara harus melindungi anak-anak dari penelantaran dan bahaya fisik atau pun mental, termasuk siksaan dan eksploitasi seksual

7. Negara-negara harus memberikan perawatan alternatif kepada anakanak yatim piatu. Proses pengangkatan anak harus diatur secara seksama dan perjanjian internasional harus diupayakan untuk memberikan rambu-rambu dan harus memastikan keabsahan yuridis, apabila ketika orangtua angkat hendak memindahkan anak dari kelahirannya

8. Anak-anak cacat harus memiliki hak atas pemeliharaan, pendidikan dan perawatan khusus

9. Anak-anak berhak atas standar kesehatan tertinggi yang dicapai. Negara harus menjamin agar perawatan kesehatan diberikan kepada semua anak, dengan menitikberatkan pada upaya-upaya preventif, pendidikan kesehatan dan penurunan tingkat kematian anak

10. Pendidikan dasar haruslah disediakan secara Cuma-Cuma dan wajib. Disiplin dalam sekolah harus menghormati harkat dan martabat anak.

11. Anak-anak harus mempunyai waktu untuk beristirahat dan bermain, mempunyai kesempatan yang sama atas kegiatan-kegiatan budaya dan seni

12. Negara-negara harus melindungi anak-anak dari eksploitasi ekonomi dan pekerjaan yang dapat merugikan pendidikan mereka, atau membhayakan kesehatan atau kesejahteraan mereka

13. Negara harus melindungi anak-anak dari penyalahgunaan obat-obatan terlarang dan keterlibatan dalam produksi atau pengedaran obat-obatan

14. Semua upaya harus dilakukan untuk menghapuskan penculikan dan per- 
dagangan anak-anak

15. Hukuman mati atau hukuman seumur hidup tidak boleh dijatuhkan bagi kejahatan yang dilakukan oleh seorang sebelum berusia 18 tahun

16. Anak-anak dalam penahanan harus dipisahkan dari orang dewasa, mereka tidak boleh disiksa atau mengalami perlakuan yang kejam atau merendahkan martabat

17. Anak di bawah usia 15 tahun tidak boleh mengambil bagian dalam pertikaian, anak-anak dalam situasi konflik bersenjata harus memperoleh perlindungan khusus

18. Anak-anak penduduk minoritas dan penduduk asli harus secara bebas menikmati budaya, agama, dan bahasa mereka sendiri

19. Anak-anak yang menderita perlakuan buruk, penelantaran atau eksploitasi harus memperoleh perawatan atau pelatihan khusus untuk menyembuhkan dan merehabilitasi mereka

20. Anak-anak yang terlibat dalam pelanggaran hukum pidana harus diperlakukan sedemikian rupa sehingga memajukan rasa harkat dan martabat mereka dan ditujukan untuk mengintegrasikan mereka ke dalam masyarakat.

Menurut Chatarina, Kepala Sub Seksi Perawatan di Rumah Detensi Imigrasi Semarang mengatakan bahwa:

"Pencari suaka dan pengungsi di sini khususnya bagi anak-anak mendapatkan akses pendidikan. Mereka mendapatkan pembelajaran berupa bimbingan belajar dan pelatihan. Tidak hanya anak-anak saja, tetapi orang dewasa laki-laki dan perempuan juga mendapatkan akses pendidikan. Kita bekerja sama dengan PKBI (Perkumpulan Keluarga Berencana Indonesia) Jawa Tengah, yang mempunyai program setiap hari senin-rabu yaitu pelatihan english class bagi semua umur, hari kamis yaitu pelatihan kreativitas class bagi anak-anak, dan hari jum'at yaitu pelatihan hand class bagi perempuan" (Wawancara, tanggal 19 Desember 2014 pukul 09.00 WIB).

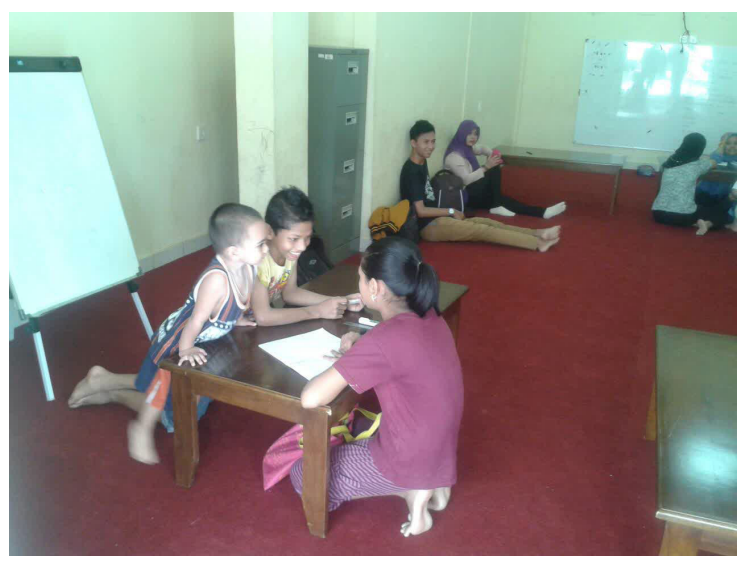

Gambar 1. Suasana Pembelajaraan di Rumah Detensi Imigrasi Semarang

Rudenim Semarang dalam periode Oktober tahun 2014 telah menampung pencari suaka anak-anak sejumlah 36 anak, terdiri dari 21 anak laki-laki dan 15 anak perempuan (Data dari seksi Registrasi, Administrasi dan Pelaporan Rumah Detensi Imigrasi Semarang Bulan Desember 2014). Pengunngsi anak-anak yang berada di Rudenim Semarang merupakan anak dari pengungsi yang masuk ke wilayah Indonesia secara bersamasama dengan keluarganya. Anak-anak tersebut sebenarnya tidak mengetahui mengapa ia dapat masuk dan ditampung di Rudenim Semarang. Meskipun mereka di tampung di Rudenim Semarang tetapi mereka tidak merasa kebebasannya untuk mendapatkan hak pendidikan terkurangi. Pasalnya pihak Rudenim Semarang telah memiliki program pembelajaran dan pelatihan yang diberikan kepada anak-anak disana. Salah satunya yaitu pelatihan english class dan kreatifitas class yang diperuntukkan bagi anak-anak.Sumber: Dokumentasi dari Peneliti

Pemenuhan hak untuk mengakses Kesehatan

Pencari suaka dan pengungsi yang berada di rumah detensi imigrasi Semarang juga berhak mendapatkan hak mengakses kesehatan. Hak atas kesehatan sebagai hak asasi manusia telah diakui dan ditur dalam berbagai instrumen internasional maupun nasional. Jaminan pengakuan hak atas kesehatan tersebut dapat dilihat dari beberapa instrumen sebagai berikut: 
1. Instrumen Internasional

a. Universal Declaration of Human Rights (UDHR)

Pasal 25

Setiap orang berhak atas taraf hidup yang menjamin kesehatan dan kesejahteraan untuk dirinya dan keluarganya, termasuk pangan, pakaian, perumahan dan perawatan kesehatannya serta pelayanan sosial yang diperlukan, dan berhak atas jaminan pada saat menganggur, menderita sakit, cacat, menjadi janda, mencapai usia lanjut atau mengalami kekurangan mata pencarian yang lain karena keadaan yang berada di luar kekuasaannya.

Para ibu dan anak-anak berhak mendapat perawatan dan bantuan istimewa. Semua anak, baik yang dilahirkan di dalam maupun di luar perkawinan, harus mendapat perlindungan sosial yang sama.

b. International Covenant on Civil and Political Rights (ICCPR).

Pasal 6

Hak untuk hidup (tidak dibunuh/dihukum mati setidaknya bagi anak di bawah 18 tahun)

Pasal 7

Hak untuk tidak disiksa, diperlakukan atau dihukum secara keji, tak manusiawi atau merendahkan martabat manusia (termasuk tidak diculik/ dihilangkan secara paksa, diperkosa)

c. International Covenant on Economic, Social and Cultural Right (ICESCR)

Pasal 12

Hak untuk menikmati standar kesehatan fisik dan mental yang tertinggi yang dapat dicapai

2. Instrumen Nasional

a. Undang-Undang Dasar 1945

Pasal $28 \mathrm{H}$ ayat (1)

Setiap orang berhak hidup sejahtera lahir dan batin, bertempat tinggal, dan mendapatkan lingkungan hidup yang baik dan sehat serta berhak memperoleh pelayanan kesehatan

b. Undang-Undang Nomor 39 tahun 1999 tentang Hak Asasi Manusia
Pasal 62

Setiap anak berhak untuk memperoleh pelayanan kesehatan dan jaminan sosial secara layak, sesuai dengan kebutuhan fisik dan mental spiritualnya.

c. Undang-Undang Nomor 23 tahun 1992 tentang Kesehatan

Pasal 4

Setiap orang mempunyai hak yang sama dalam memperoleh derajat kesehatan yang optimal (Afandi, 2008: $3)$.

Dalam Pasal 12 ayat (1) International Covenant on Economic, Social and Cultural Right (ICESCR) hak atas kesehatan dijelaskan sebagai "hak setiap orang untuk menikmati standar tertinggi yang dapat dicapai atas kesehatan fisik dan mental" tidak mencakup area pelayanan kesehatan (Afandi, 2008: 3). Rudenim Semarang menampung sebanyak 82 orang, yang terdiri dari 49 orang laki-laki dan 33 orang perempuan (Data dari seksi Registrasi, Administrasi dan Pelaporan Rumah Detensi Imigrasi Semarang Bulan Desember 2014). Menurut Catharina selaku Kepala Sub Seksi Perawatan mengatakan bahwa :

"Untuk perawatan kesehatan pihak rumah detensi imigrasi Semarang memiliki program pelayanan kesehatan yang diperuntukkan bagi para deteni setiap hari Senin dan Kamis. Rudenim Semarang bekerja sama dengan Rumah Sakit untuk memberikan pelayanan kesehatan bagi para deteni. Karena pihak rudenim semarang sendiri tidak mempunyai tenaga ahli medis di bidang kesehatan" (Wawancara, tanggal 19 Desember 2014 pukul 09.00 WIB).

Pemenuhan hak hidup (untuk mendapatkan makanan)

Pengungsi merupakan individu yang meninggalkan negaranya atau tempat tinggal sehari-harinya karena takut atas penganiayaan. Dan seorang pengungsi dilindungi 
segala hak-haknya oleh Konvensi Pengungsi 1951. Masalah pengungsi saat ini telah menyebar luas ke seluruh dunia. Perang, bencana alam, kemiskinan menjadi faktor yang menyebabkan orang-orang memilih menjadi pengungsi. Secara umum, terdapat dua faktor mengapa orang pergi meninggalkan tempat tinggalnya secara terpaksa.

Pertama, Natural disaster, yaitu bencana alam yang menyebabkan kerusakan infrastruktur kehidupan sehingga orang-orang terpaksa meninggalkan sementara tempat tinggalnya. Pengungsi seperti ini hanya membutuhkan bantuan dasar hidup seperti makanan, pakaian, tempat penampungan, kesehatan. Ketika keadaan alam kembali normal, maka pengungsi tersebut akan kembali ke daerah asalnya secara sukarela.

Kedua, Human made disaster, yaitu faktor manusia yang menyebabkan pengungsi meninggalkan rumahnya secara terpaksa. Faktor ini biasanya berupa perang saudara, kekerasan politik, pelanggaran HAM, diskriminasi sosial. Pengungsi seperti ini tidak hanya saja memerlukan bantuan dasar hidup, akan tetapi memerlukan perlindungan internasional bahkan memerlukan tempat tinggal permanen yang baru (Krustiyati, 2012: 15).

Setiap manusia di dunia ini pasti memiliki HAM yang telah mereka bawa sejak mereka di lahirkan. HAM adalah hak-hak yang memang seharusnya di dapat oleh setiap individu dimanapun mereka berada. Akan tetapi, setiap individu juga harus memenuhi tugas dan kewajibannya dahulu sebelum menuntut hak-hak mereka. Tak terkecuali bagi mereka para imigran gelap yang masuk ke Indonesia. Walaupun memang sebenarnya mereka telah melanggar hukum di Indonesia, dengan masuk ke dalam wilayah Indonesia secara ilegal dan tanpa dokumen yang lengkap. Bahkan, banyak dari para imigran gelap itu yang tinggal dan sudah menetap lama di berbagai wilayah di Indonesia ini.

Sebenarnya, imigran gelap yang ada di Indonesia tidak hanya mereka yang memang masuk secara ilegal untuk menetap disini atau memang sudah tinggal lama disini namun tidak punya dokumen lengkap tentang diri mereka.

Para pengungsi dari negara lain dan para pencari suaka yang masuk secara ilegal ke wilayah negara ini juga di kategorikan sebagai imigran gelap. Mereka bukannya tanpa alasan menjadi imigran gelap, selain karena takut akan penyiksaan atau ancaman penyiksaan (persecution) yang terjadi atas dasar perbedaan suku, agama, ras, etnis, golongan sosial, keyakinan politik, kelompok kepentingan, dan lain-lain, mungkin mereka juga telah hilang harapan terhadap keamanan dirinya di negeri asalnya. Itulah yang mendasari mereka untuk mencari kehidupan lain yang lebih layak walaupun cara yang mereka tempuh salah.

Walaupun imigran gelap jelas-jelas menyalahi aturan yang ada di Indonesia, tapi mereka juga mempunyai hak asasi yang patut di pertimbangkan oleh pemerintah Indonesia. Pemerintah tidak boleh langsung memberi hukuman atau langsung mendeportasi para imigran gelap. Pemerintah juga perlu mempertimbangkan keberlangsungan hidup para imigran gelap dan tentunya mempertimbangkan hak asasi mereka.

Tetapi di indonesia sendiri dalam penanganan imigran gelap memang sangat menjunjung tinggi HAM yang berlaku. Buktinya para imigran gelap yang tertangkap di perlakukan secara baik. Malah, mereka terkesan betah dengan perlakuan pihak negara kita. Dibandingkan negara-negara lain, dalam penanganan imigran gelap, memang negara kita lah yang paling unggul. Di Indonesia HAM untuk imigran gelap memang ditegakkan dengan adil.

Imigran gelap atau bisa disebut juga dengan pencari suaka yang berada di wilayah Indonesia akan ditampung di Rudenim. Dalam hal melindungi hak asasi dari orang asing, Rudenimlah yang sangat penting. Bagaimana tidak, kehidupan sehari-hari para pencari suaka berada di Rudenim untuk menunggu hasil keputusan dari UNHCR mengenai status pengungsi. Para pencari suaka juga berhak untuk hidup tanpa penyiksaan. Dari sinilah peneliti akan mengkaji mengenai Rumah Detensi Imigrasi dalam perlindungan hak hidup (untuk mendapatkan makanan) bagi para pencari suaka khususnya para pencari suaka di Rudenim Semarang.

Hak hidup yang dikhususkan yaitu hak 
untuk mendapatkan makanan bagi warga negara asing di rumah detensi imigrasi semarang. Menurut Pasal 6 ayat (1) ICCPR "Every human being has the inherent right to life. This right shall be protected by law. No one shall be arbitrarily deprived of his life". Hak untuk hidup termasuk klasifikasi Non-Derogable Rights, yang artinya hak-hak yang bersifat absolut yang tidak boleh dikurangi pemenuhannya oleh siapapun, walaupun dalam keadaan darurat sekalipun (Budiardjo, 2008: 222).

Berdasarkan pernyataan diatas maka hak hidup yaitu hak untuk mendapatkan makanan dalam pemenuhannya tidak dapat dikurangi oleh siapapun. Dalam hal untuk mendapatkan pemenuhan hak hidup, para deteni yang ada di Rudenim Semarang diberikan jatah makanan setiap hari 3 (tiga) kali, yaitu pagi, siang dan malam oleh Rudenim Semarang. Rudenim Semarang memberikan makanan kepada deteni dengan memesan catering nasi kotak yang mana untuk jatah satu deteni makan 3 (tiga) kali sehari menghabiskan Rp. 30.000,00 (Tiga puluhribu rupiah). Rudenim Semarang mendapatkan sumber dana untuk memberikan pemenuhan hak atas makanan para deteni yang berada di sana berasal dari IOM (International Oganization for Migration). Disini Rudenim Semarang hanya sebagai perantara dari IOM untuk tetap memberikan pemenuhan hak hidup yaitu hak untuk mendapatkan makanan bagi para deteni.

Para deteni yang berada di Rudenim Semarang biasanya memiliki selera sendiri terhadap makanannya. Sehingga tak jarang jatah makanan yang diberikan kepada mereka oleh Rudenim Semarang tidak dimakan. Rudenim Semarang juga menyadari bahwa tidak mampu untuk memberikan makanan yang sesuai dengan selera para deteni yang beraneka ragam yang dikarenakan Rudenim Semarang tidak memiliki staff khusus untuk memasak dalam rangka memberikan jatah makanan kepada deteni sesuai selera mereka. Namun, Rudenim Semarang menyediakan dapur untuk para deteni yang ingin memasak makanannya sendiri. Dan Rudenim Semarang pun disetiap minggunya memberikan kebutuhan pokok bagi deteni. Semua pembiayaan kebutuhan bagi deteni bersum- ber dari IOM (International Oganization for Migration).

Menurut Catharina selaku Kepala Sub Seksi Perawatan mengatakan bahwa :

"Hak untuk mendapatkan makanan, disini rumah deteni imigrasi Semarang setiap harinya menyediakan makanan siap makan yang layak bagi para deteni. Akan tetapi bagi para pencari suaka dan pengungsi disini biaya untuk kehidupan sehari-hari semua ditanggung oleh IOM. Bisa dikatakan bahwa rudenim semarang ini hanya memberikan fasilitas saja. Biasanya IOM memberikan dana untuk makan yaitu Rp. 30.000, 00 (tiga puluh ribu rupiah) per-orang" (Wawancara, tanggal 19 Desember 2014 pukul 09.00 WIB).

Dari penjelasan di atas, Rudenim Semarang dalam perlindungan hak asasi manusia bagi warga negara asing sudah terwujud melalui program-program yang diperuntukkan oleh para deteni di bidang hak atas pendidikan, hak atas kesehatan dan hak hidup yaitu hak untuk mendapatkan makanan. Rudenim Semarang dapat dikatakan sudah mampu serta dapat melindungi dan memberikan perlindungan hak asasi manusia bagi para deteninya sehingga meskipun para deteni tersebut di tempatkan di tempat penampungan, mereka tetap dapat merasakan hak-haknya terpenuhi dan dilindungi oleh Rudenim Semarang.

Dengan demikian Rudenim Semarang telah memberikan perlindungan hak asasi manusia bagi warga negara asing yang berada disana sebagai mana yang telah diatur dalam Pasal 15 Peraturan Direktur Jendral Imigrasi Nomor F-1002.PR.02.10 Tahun 2006 tentang Tata Cara Pendetensian Orang Asing yang menyebutkan hak-hak yang dimiliki oleh orang asing yang berada di Rumah Detensi Imigrasi yaitu :

1. Melaksanakan ibadah menurut agama dan kepercayaan masing-masing dalam waktu dan tempat yang telah disediakan;

2. Mendapat perawatan, baik perawatan rohani maupun jasmani;

3. Mendapat pelayanan kesehatan dan 
makanan yang layak;

4. Menyampaikan keluhan;

5. Menerima kunjungan keluarga, sponsor, penasihat hukum, rohaniawan, dokter atau Perwakilan Negara.

Hak-hak yang dimiliki oleh warga negara asing yang berada di Rudenim Semarang terpenuhi melalui program di bidang hak atas pendidikan, hak atas kesehatan dan hak hidup yaitu hak untuk mendapatkan makanan yang diselenggarakan oleh Rudenim Semarang. Dimana Rudenim Semarang dalam membuat kegiatan tersebut memiliki tujuan yang sama dengan ketentuan Peraturan Direktur Jendral Imigrasi Nomor F-1002. PR.02.10 Tahun 2006 tentang Tata Cara Pendetensian Orang Asing terkait hak-haknya.

Rudenim Semarang berkoordinasi baik secara internal yakni berkoordinasi dengan antar sub bidang serta juga berkoordinasi dengan pihak luar dalam hal ini pihak-pihak yang terkait dan dapat mendorong Rudenim dalam memberikan perlindungan hak asasi manusia bagi warga negara asing. Hal demikian adalah suatu upaya yang inovatif dari rudenim semarang dalam rangka memberikan perlindungan hak asasi manusia sekaligus melaksanakan penegakan hukum keimigrasian Indonesia.

Rumah detensi imigrasi Semarang telah menampung orang asing yang terbagi dalam 2 (dua) kategori yaitu, Immigratoir dan Under IOM. Immigratoir merupakan orang asing yang memasuki wilayah Indonesia yang secara reguler adalah resmi (dengan cara yang resmi), tetapi sesungguhnya menggunakan dokumen yang dipalsukan atau menggunakan dokumen resmi milik seseorang yang bukan haknya, atau dengan menggunakan dokumen resmi dengan tujuan yang ilegal atau orang asing yang tetap tinggal di Indonesia setelah habis masa berlakunya status resmi sebagai imigran resmi. Sedangkan Under IOM adalah orang asing yang memasuki wilayah Indonesia secara tidak resmi yaitu tidak membawa dokumen keimigrasian, namun orang asing tersebut mengaku bahwa mereka pencari suaka dan pengungsi.

Rudenim Semarang sampai saat ini menampung deteni sebanyak 87 orang, paling banyak adalah dari negara Myanmar.
Deteni yang berada di Rudenim Semarang sebagian besar berasal dari negara Myanmar. Menurut Sulhan, Kepala Sub Seksi Keamanan di Rumah Detensi Imigrasi Semarang mengatakan bahwa :

“Deteni yang banyak menghuni di Rudenim Semarang ini adalah sebagian besar pencari suaka dari warga negara Myanmar. Alasan mereka mencari suaka di Indonesia karena beberapa faktor, yaitu Indonesia mayoritas pendudukannya beragama muslim, budaya masyarakat Indonesia yang ramah dengan orang asing, serta letak Indonesia yang berdekatan dengan Myanmar, sehingga memudahkan mereka untuk masuk dan menjangkau wilayah teritorial Indonesia melalui jalur laut, meskipun tujuan negara mereka adalah negara Australia" (Wawancara, tanggal 12 November 2014 pukul $10.00 \mathrm{WIB})$.

Sejalan dengan pernyataan Sulhan, ada beberapa faktor pendorong dan penarik yang dikemukakan oleh Wagiman (2012: 83) berkaitan dengan mengapa deteni yang berada di Rudenim kebanyakan berasal dari negara Myanmar. Berikut adalah faktor dan penariknya :

1. Faktor Pendorong

a. Konflik yang berkepanjangan di negara asal terkait dengan aspek politik, keamanan, sukuisme, dan lain-lain.

b. Keadaan ekonomi dan kampung halaman yang buruk sebagai akibat dari konflik tersebut (keinginan untuk memperoleh kehidupan yang lebih baik).

c. Bujukan dari agen penyelundupan manusia.

2. Faktor Penarik

a. Letak geografis Indonesia sangat strategis untuk melintas ke Australia (didukung dengan kelemahan bidang keamanan dan pengawasan perbatasan RI).

b. Tersebarnya info bahwa UNHCR di Indonesia melakukan RSD (Refugee Status Determination) lebih cepat 
Tabel 1. Jumlah Deteni di Rumah Detensi Imigrasi Semarang s/d Desember 2014

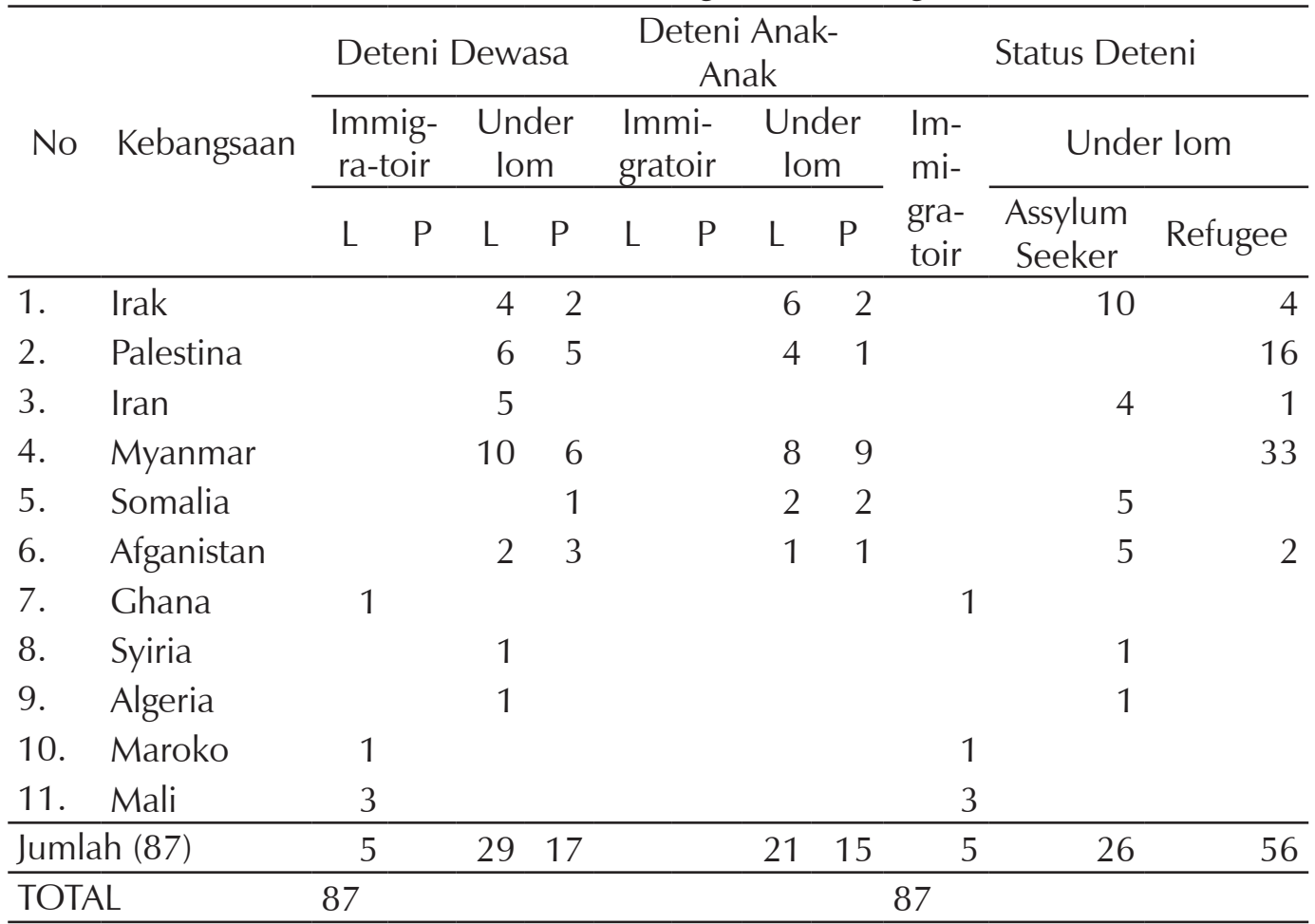

Sumber: Kearsipan Bidang Registrasi, Administrasi dan Pelaporan Rumah Detensi Imigrasi Semarang tahun 2014

dari UNHCR di Malaysia (jumlah imigran ilegal berstatus pencari suaka dan pengungsi maupun yang telah ditolak dan belum terdaftar di Malaysia lebih dari 40 ribu orang, di Indonesia "hanya" \pm 2 ribu orang).

c. Kultur masyarakat Indonesia yang terkesan "dapat menerima" pendatang baru (mayoritas muslim).

Mengenai pelanggaran hukum Indonesia yang dilakukan oleh warga negara asing, telah dilakukan penelitian oleh Mulhadi (2014: 55), yang menyimpulkan bahwa: Perlindungan internasional terhadap pengugsi diatur dalam Konvensi 1951 dan Protokol 1967. Dalam Kovesi 1951 dan Protokol 1967 terdapat ketentuan yang berisikan apa yang menjadi hak-hak dan kewajiban para pengungsi seperti hak untuk tidak dipulangkan ke negara asalnya. Selain mendapatkan hak-haknya, pengungsi juga dibebankan beberapa kewajiban seperti menghormati dan mematuhi hukum yang berlaku di negara ia berada dan kewajiban membayar pajak dan biaya-biaya fiskal lainnya (Mulhadi, 2014:
55).

Dalam menangani pengungsi dan pencari suaka yang berada di Indonesia menurut Mulhadi, diperlukan kerjasama internasional yang menangani imigran atau berhubungan dengannya, seperti Komisi PBB untuk Urusan Pengungsi (UNHCR), Organisasi Internasional yang Mengungsi Migran (IOM) juga sangat penting. Konsep perlindungan yang diberikan oleh UNHCR adalah lebih menekankan pada usaha pengembangan instrumen hukum internasional untuk kepentingan para pengungsi dan memastikan agar mereka mendapat perlakuan sesuai dengan ketentuan instrumen hukum internasional, khususnya yang bekaitan dengan hak untuk bekerja, jaminan sosial, serta hak untuk mendapatkan atau memanfaatkan fasilitas perjalanan. Sedangkan peran IOM dalam menangani pengungsi dan pencari suaka di Indonesia adalah mengurus dan menjamin kehidupan para pengungsi dan pencari suaka dengan memberikan tempat penampungan (rudenim) (Mulhadi, 2014: 55). 


\section{b. Faktor pendukung dan penghambat yang pemenuhan HAM pencari suaka}

\section{Faktor Pendukung}

Rudenim Semarang dalam memberikan perlindungan hak asasi manusia bagi para deteni yang berada disana guna menunggu kepastian dari UNHCR untuk ditempatkan dinegara ketiga. Rudenim Semarang dalam memberikan perlindungan hak asasi manusia dari para deteninya diwujudkan melalui program kegiatan yang diadakan oleh rudenim Semarang.

Pertama, dalam hal pemenuhan hak atas pendidikan bagi para deteni, rudenim Semarang bekerjasama dengan PKBI Jawa Tengah dimana program pendidikan itu dilakukan di dalam ruangan yang telah disediakan rudenim, pendidikan yang diajarkan kepada para deteni dilaksanakan melalui kelas-kelas khusus yang mana kegiatannya disesuaikan dengan umur serta gender dari para deteni yaitu pelatihan hand class diperuntukan bagi para deteni wanita dewasa, english class diperuntukan bagi semua deteni dengan materi pembelajaran bahasan inggris yang disesuakan dengan umur serta kreatifitas class yang diperuntukkan bagi anak-anak. Partisipasi dari para deteni juga merupakan faktor pendukung dalam hal Rudenim Semarang memberikan pemenuhan hak atas pendidikan melalui kegiatan-kegiatan yang selalu diikuti oleh para deteni. Tak jarang juga para deteni memberikan masukkan terhadap program kegiatan pendidikan kepada Rudenim Semarang agar diberikan pendidikan kesenian budaya asli Indonesia.

Kedua, dibidang pemenuhan hak hidup yang dikhususkan yaitu hak untuk mendapatkan makanan bagi para deteni, rudenim semarang juga telah memberikan pemenuhanan makanan bagi para deteni dimana rudenim semarang menggunakan sumber dana yang berasal dari IOM untuk memberikan makanan yang siap makan dan layak setiap harinya untuk para deteni sebanyak 3 (kali) dalam sehari, sehingga para deteni dirudenim Semarang tidak pernah kekurangan makanan. Selain itu Rudenim Semarang menyediakan dapur bagi para deteni untuk memasak. Dapur yang berada di Rudenim
Semarang merupakan salah satu alternatif guna mengatasi kebosanan para deteni atas makanan yang diberikan oleh Rudenim yang terkadang makanan yang diberikan tidak sesuai selera mereka.

Ketiga, dalam hal pemenuhan hak atas kesehatan. Rudenim Semarang sangat memperhatikan hal itu dimana dirudenim Semarang setiap hari Senin dan Kamis diadakan program pelayanan kesehatan yang diperuntukkan bagi para deteni. Rudenim Semarang bekerja sama dengan Rumah Sakit untuk memberikan pelayanan kesehatan bagi para deteni. Karena pihak rudenim semarang sendiri tidak mempunyai tenaga ahli medis di bidang kesehatan. Selain itu juga Rudenim Semarang menyediakan obat-obatan maupun vitamin bagi deteni untuk menjaga kesehatan mereka.

Rudenim seperti yang telah dideskripsikan diatas, tentu tidak terlepas dari faktorfaktor yang dapat mendukung perwujudan Rudenim Semarang dalam memberikan perlindungan hak atas pendidikan, kesehatan serta makanan bagi para deteni. Faktor pendukung terkait sarana atau fasilitas pendukung dari suatu instansi atau birokrasi, menurut M.Mas'ud Said dapat dibagi menjadi 3 (tiga) bagian sebagai berikut :

1. Fasilitas pendukung operasional kerja seperti gedung kantor, peralatan kantor, komputer, kendaraan dinas dan sebagainya. Pada intinya fasilitas ini adalah fasilitas berupa barang atau mesin untuk mendukung operasional kerja sehari-hari dari aparatur birokrasi.

2. Fasilitas pendukung insentif kerja seperti gaji, tunjangan pensiun dan sebagainya. Fasilitas ini adalah fasilitas pendukung yang mendukung semangat dan loyalitas kerja dari aparatur birokrasi. Mengenai gaji Bintoro menyatakan bahwa secara ideal gaji pegawai dan sistemnya harus memenuhi tiga unsur yaitu : adil, cukup dan merangsang serta berorientasi pada prestasi kerja. Oleh karena menjadi pegawai negeri diharapkan merupakan suatu karier dalam hidup, maka perlu kiranya gaji yang wajar dihubungkan dengan beratnya beban tugas, tang- 
gung jawab, kualifikasi, prestasi kerja, lamanya menjabat dan tingkat biaya hidup.

3. Fasilitas pendukung administrasi kerja seperti sistem akuntansi, sistem pengawasan, sistem pelaporan, dan sebagainya. Pada intinya, fasilitas ini berupa sistem yang bisa menjadi alat ukur dan alat kontrol objektif yang bisa membantu aparatur birokrasi untuk menilai dan mengawasi kerja dan kinerja secara keseluruhan sebagai aparatur birokrasi (Said, 2007: 109).

Dalam hal pemenuhuan hak atas pendidikan, kesehatan serta makanan bagi para deteni rudenim semarang secara umum telah memiliki fasilitas pendukung diantaranya adalah ketersediaan bangunan yang layak untuk melaksanakan perannya, Himawan Kepala Sub Seksi Administrasi dan Pelaporan Rudenim Semarang menegaskan bahwa :

"Hak asasi yang dimiliki para deteni yang berada di rudenim semarang ini wajib dijaga, hak-hak yang dimiliki para deteni telah dicantumkan dalam Peraturan Jendral Imigrasi. Kita pihak rudenim semarang dalam pemenuhan hak-hak para deteni telah menyiapkan sarana dan prasarana yang mendukung agar program-program bisa berjalan secara lancar, salah satunya adalah ruang untuk pelayanan cek kesehatan dan ruang untuk pembelajaran dalam bidang pendidikan" (Wawancara, tanggal 19 Desember 2014 pukul 10.00 WIB).

Selain ketersediaan bangunan yang layak, faktor pendukung yang lain adalah partisipasi dari para deteni yang sangat tinggi, sehingga dalam setiap program kegiatan yang diadakan oleh rudenim semarang seperti dibidang pendidikan, kesehatan serta makanan dapat berjalan secara lancar. Menurut Catharina selaku Kepala Sub Seksi Perawatan menegaskan bahwa :

"Rudenim dalam melindungi hak para deteni sangat terbantu dengan partisipasi dan antusiasme dari para deteni dalam program-progam yang diadakan oleh ru- denim semarang, sehingga setiap program yang diadakan dalam rangka pemenuhan hak-hak dari para deteni dapat terlaksana dan dapat berjalan secara lancar" (Wawancara, tanggal 19 Desember 2014 pukul 09.00 WIB).

Selain faktor bangunan yang layak dan partisipasi dari para detensi, faktor pendukung yang lain adalah pihak Rudenim Semarang menjalin kerja sama dengan pihak-pihak lain, seperti Rumah Sakit, PKBI, dan Rumah Zakat. Himawan, Kepala Sub Seksi Administrasi dan Pelaporan Rudenim Semarang menegaskan bahwa :

"Selain dari faktor bangunan yang layak, faktor pendukung yang lain adalah rudenim semarang bekerja sama dengan pihak lain dalam pemenuhan hak-hak bagi para deteni disini, kita bekerja sama dengan Rumah sakit dalam bidang kesehatan, Rumah Zakat dan PKBI dalam bidang kesehatan untuk memberikan pembelajaran ataupun pelatihan bagi para deteni disini" (Wawancara, tanggal 19Desember 2014 pukul $10.00 \mathrm{WIB}$ ).

Tekait perwujudan Rudenim Semarang, Soerjono Soekanto (2014: 8) mengemukakan teori efektifitas hukum. Efektifitas hukum dalam hal ini kaitannya adalah peran dari rudenim Semarang yanng mana menurut teori tersebut dipengaruhi oleh beberapa faktor, yaitu :

1. Faktor hukumnya sendiri (Undang-Undang).

2. Faktor penegak hukum, yakni pihak-pihak yang membentuk maupun menerapkan hukum.

3. Faktor sarana atau fasilitas yang mendukung penegakan hukum.

4. Faktor masyarakat, yakni lingkungan dimana hukum tersebut berlaku atau diterapkan.

5. Faktor kebudayaan, yakni sebagai hasil karya, cipta dan rasa yang didasarkan pada karsa manusia di dalam pergaulan hidup.

Mengenai faktor hukumnya sendiri, bahwa berdasarkan Peraturan Menteri Hukum dan HAM Nomor M.05.IL.02.01 Tahun 
2006 tentang Rumah Detensi Imigrasi telah dibentuklah Rumah Detensi Imigrasi yang sesuai dengan kriteria dalam ketentuan Keputusan Menteri Kehakiman dan HAM Republik Indonesia Nomor: M.01-PR.07.04 Tahun 2004 tentang Organisasi dan Tata Kerja Rumah Detensi Imigasi serta berpedoman pada Peraturan Direktur Jendral Imigrasi Nomor F-1002.PR.02.10 Tahun 2006 tentang Tata Cara Pendetensian Orang Asing. Dengan demikian diharapkan dan sudah sepatutnya Rumah Detensi Imigrasi Semarang mampu menjalankan dan mewujudkan perannya dibidang keimigrasian. Terbukti Rudenim Semarang mampu memberikan perlindungan dan pemenuhan hak atas pendidikan, hak atas kesehatan dan hak hidup dalam hal ini untuk mendapatkan makanan meskipun belum sepenuhnya dapat dikatakan optimal dikarenakan masih ada faktor yang dapat dikatakan menghambat.

Faktor berikutnya mengenai penegak hukum, yakni pihak-pihak yang membentuk maupun menerapkan hukum. Dalam Rudenim Semarang yang termasuk aparat penegak hukumnya adalah para pegawai dalam Rudenim Semarang itu sendiri. Disini dapat dikatakan bahwa para pegawai di Rudenim Semarang dilihat dari kualitasnya sudah memadahi, dimana mereka menguasi bahasa inggris sehingga mampu berkomunikasi dengan para deteni. Sedangkan dilihat dari segi kuantitasnya, Rudenim Semarang masih kekurangan pegawai sehingga dalam melaksanakan perannya sedikit terhambat.

Faktor yang terakhir yaitu faktor sarana atau fasilitas yang mendukung penegakan hukum. Rudenim Semarang dalam melaksanakan perannya sedikit kurang tertunjang dalam hal gedung yang memadahi. Dalam memberikan perlindungan hak atas kesehatan, Rudenim Semarang belum dapat berperan secara optimal dikarenakan di Rudenim Semarang belum ada ruangan khusus yang difungsikan untuk memberikan pelayanan kesehatan khususnya ruang rawat inap dan IGD. Dengan demikian dapat dikatakan Rudenim Semarang belum optimal dalam melaksanakan perannya.

\section{Faktor Penghambat}

Perlindungan hak asasi manusia bagi warga negara asing yang ditampungi di Rudenim Semarang dalam pelaksanaannya terkadang menemui suatu kendala yang menyebabkan pelaksanaan perlindungan hak asasi manusia para deteni oleh Rudenim Semarang sedikit terhambat. Meskipun demikian perlindungan atas hak asasi manusia bagi warga negara asing oleh Rudenim Semarang selalu diupayakan agar dapat berjalan secara efektif. Faktor-faktor penghambat dalam perlindungan hak asasi manusia bagi warga negara asing yang dihadapi oleh Rudenim Semarang diantaranya adalah :

Pertama, seperti dibidang kesehatan meskipun rudenim telah memiliki ruang khusus untuk memberikan pelayanan kesehatan bagi para deteni serta telah bekerjasama dengan rumah sakit setempat untuk ketersediaan tenaga medisnya, namun fasilitas pendukung dibidang kesehatan yang dimiliki rudenim semarang kurang memadai seperti tidak tersedianya ruang perawatan gawat darurat, minimnya sarana dan prasarana serta pengetahuan di bidang kesehatan, tidak adanya tenaga medis yang menjaga 24 jam sehingga ketika ada urusan kesehatan yang bersifat darurat rudenim semarang kurang dapat menanganinya. Sejalan dengan toeri efektifitas hukum yang dikemukakan oleh Soerjono Soekanto yakni faktor sarana atau fasilitas pendukung maka Rudenim Semarang menjadi terhambat dalam memberikan pelayanan atas kesehatan, namun untuk mensiasati hal tersebut pihak rudenim membuat kebijaksanaan dengan menyediakan petugas jaga yang bertugas 24 jam serta bekerjasama dengan rumah sakit yang siap memberikan fasilitas ambulance ketika ada urusan yang mendesak atau gawat darurat dan rudenim Semarang memperbolehkan deteninya yang membutuhkan perawatan kesehatan yang bersifat darurat untuk keluar menuju rumah sakit dengan tetap memberikan pengawalan pada deteni tersebut. Serta belum adanya gudang untuk menyimpan peralatan kebutuhan hidup para deteni dan kuranganya staf pada Seksi Perawatan dan Kesehatan.

Kedua, dalam hal pemenuhan maka- 
nan rudenim semarang tidak memiliki dapur umum yang menyediakan makanan untuk para deteni melainkan rudenim Semarang berperan sebagai perantara pelaksana teknis untuk menggunakan sumber dana yang bersumber dari IOM untuk digunakan dalam rangka menjamin kelangsungan hidup deteni dalam rangka untuk pemenuhan makanan. Rudenim membelanjakan makanan melalui catering dengan jumlah dan harga yang telah disesuai dengan ketentuan yang diatur oleh IOM dimana untuk setiap harinya perdeteni mendapatkan jatah makanan sebesar 30 ribu. Dan juga para deteni terkadang bosan terhadap pemberian menu makan yang telah diberikan dikarenakan para deteni tersebut ingin makanan yang berasal dari negaranya.

Ketiga, di bidang pendidikan dalam memenuhi hak atas pendidikan para deteni Rudenim Semarang terhambat dengan Sumber Daya Manusia yaitu tenaga pengajar yang memberikan pembelajaran bagi para deteni. Selain itu juga faktor bahasa menjadi kendala utama dalam memberikan hak atas pendidikan dimana saat kegiatan di bidang pendidikan yang diadakan oleh Rudenim Semarang menjadi kurang komunikatif dikarenakan warga negara asing yang berada disana belum semuanya dapat berbahasa inggris, begitu pula tenaga pengajar. Serta Sumber Daya Manusia dari pihak Rudenim Semarang juga sangat kurang. Tenaga yang dibutuhkan untuk menjaga para deteni sangatlah kurang, sehingga pihak Rudenim Semarang membutuhkan tenaga untuk menjaga selama 24 jam. Sejalan dengan toeri efektifitas hukum yang dikemukakan oleh Soerjono Soekanto yakni terkait faktor penegakan hukum maka Rudenim Semarang menjadi terhambat dikarenakan deteni yang butuh pelayanan tidak sebanding jumlahnya dengan pegawai yang ada di Rudenim Semarang. Menurut Himawan, Kepala Sub Seksi Administrasi dan Pelaporan Rudenim Semarang menegaskan bahwa :

"Memang Rudenim Semarang dalam memberikan perlindungan hak asasi manusia bagi warga negara asing mengalami beberapa kendala, yaitu kurangnya Sumber Daya Manusia untuk menjaga disini selama 24 jam, tidak adanya tenaga medis yang berdiam disini, terkadang para deteni juga pilihpilih dalam menu makanan, namun pihak rudenim sendiri akan tetep melindungi hak asasi manusia bagi para deteni semaksimal mungkin" (Wawancara, tanggal 19 Desember 2014 pukul 10.00 WIB).

Berkitan dengan sumber daya manusia dari pegawai Rudenim Semarang dalam memberikan pemenuhan hak asasi manusia menjadi terkendala sejalan dengan pendapat dari Notoatmojo (2005) yang melihat sumber daya manusia dari dua aspek yaitu :

a. Mutu dan kualitas yang diukur melalui kemampuan fisik seperti kesehatan jasmani, kekuatan untuk bekerja dan kemampuan non fisik misalnya kecerdasan dan mental.

b. Jumlah atau kuantitas yaitu banyaknya sumber daya sebagai tenaga kerja dalam suatu organiasi.

Lebih lanjut Notoatmojo (2005) mengatakan bahwa, manfaat sumber daya manusia dalam suatu organisasi memegang peranan penting. Fasilitas yang canggih dan lengkap pun belum merupakan jaminan akan keberhasilan suatu lembaga, tanpa diimbangi kualitas dari staf atau karyawan yang akan memanfaatkan fasilitas itu.

Rumah Detensi Imigrasi Semarang jika dilihat dari segi sumber daya manusia yaitu mutu dan kualitasnya maka Rudenim Semarang telah dapat dikatakan memnuhi standar mutu sumber daya manusia yang baik, dimana para staff pegawai di Rudenim Semarang rata-rata berpendidikan Strata-1. Hal ini sudah dapat menjadi tolak ukur atas mutu dan kualitas dari para pegawai. Sedangkan dilihat dari jumlah sumber daya manusia dari pegawai di Rudenim Semarang masih sangat kurang memadai, sehingga Rudenim Semarang terkadang sedikit terkendala dikarenakan jumlah dari pegawai yang menangani dan melayani kebutuhan deteni tidak sebanding dengan jumlah deteni yang harus ditangani dan dilayani.

\section{Simpulan}


Berdasarkan hasil penelitian ini dapat disimpulkan bahwa Rumah Detensi Imigrasi Semarang telah memberikan perlindungan hak asasi manusia bagi warga negara asing pencari suaka sebagai mana yang telah diatur dalam Pasal 15 Peraturan Direktur Jendral Imigrasi Nomor F-1002.PR.02.10 Tahun 2006 tentang Tata Cara Pendetensian Orang Asing. Rumah Detensi Imigrasi memberikan pemenuhan hak asasi manusia bagi pencari suaka yang berada disana dengan cara memberikan program-program, seperti pemenuhan hak atas pendidikan yaitu memberikan pelatihan dan bimbingan berlajar setiap hari Senin sampai Kamis, pemenuhan hak atas kesehatan yaitu memberikan pelayanan kesehatan setiap hari Senin dan Kamis, serta pemenuhan hak hidup (untuk mendapatkan makanan) diberikan jatah makan 3 (tiga) kali dalam sehari yaitu pagi, siang dan malam.

Berdasarkan hasil penelitian ini dapat disimpulkan bahwa faktor pendukung dalam Rumah Detensi Imigrasi Semarang mewujudkan perlindungan dan pemenuhan hak asasi manusia bagi para pencari yaitu partisipasi dari para pencari suaka untuk mengikuti program-program yang diberikan, disamping itu Rumah Detensi Imigrasi telah memiliki sarana dan prasarana yang memadai serta berkerjasama dengan PKBI dalam bidang pendidikan dan Rumah Sakit dalam bidang kesehatan. Sedangkan faktor penghambat bagi Rumah Detensi Imigrasi Semarang untuk mewujudkan perlindungan dan pemenuhan hak asasi manusia bagi pencari suaka yaitu perbedaan bahasa dalam berkomunikasi dikarenakan warga negara asing tersebut mrnggunakan bahasa yang berasal dari negaranya. Disamping itu tidak tersedianya ruangan gawat darurat dan tenaga medis yang menjaga 24 jam, dan dilihat dari ketersediaan jumlah, baik pegawai di Rumah Detensi Imigrasi Semarang dan tenaga pengajar kurang memadahi untuk memberikan pelayanan dalam mewujudkan perlindungan dan pemenuhan hak asasi bagi pencari suaka.

Saran yang diberikan: (1) Diharapkan kepada Rumah Detensi Imigrasi Semarang untuk lebih menambah sumber daya manusia disana guna mewujudkan perlindungan dan pemenuhan hak asasi bagi pencari suaka; (2) Diharapkan koordinasi dengan instansi terkait lebih ditingkatkan lagi agar tercipta suatu hasil kinerja yang maksimal dalam pemenuhan hak asasi manusia bagi para pencari suaka; dan (2) Diharapkan Pemerintah Indonesia melalui Kementerian Hukum dan HAM RI membuat kebijakan yang jelas terkait status pencari suaka di Indonesia guna tetap dapat menjaga kestabilan negara meskipn tidak meratifikasi Konvensi 1951 dan Protokolnya, sehingga tetap terciptanya kepastian hukum dibidang keimigrasian terkait pencari suaka.

\section{Daftar Pustaka}

Afandi, Dedi. 2008. Hak Atas Kesehatan dalam Perapektif HAM. Jilid 2 No. 1 Maret 2008.

Amiruddin. 2012. Pengantar Metode Penelitian Hukum. Jakarta: PT Raja Grafindo Persada.

Arifin, Saru. 2014. Hukum Perbatasan Darat Antarnegara. Jakarta: Sinar Grafika.

Budiardjo, Miriam. 2008. Dasar-dasar Ilmu Politik. Jakarta: PT Gramedia Pustaka Utama.

Enggal, Paulus. 2012. Refugee. http://jrs.or.id/refugee/, (diakses tanggal 12 Oktober 2014 20.55)

Faizal, Eka Rendytia. 2013. (Skripsi). Peran dan Fungsi Kantor Wilayah Kementerian Hukum dan HAM Jawa Tengah dalam Pelaksanaan Pengawasan dan Penindakan Keimigrasian terhadap Orang Asing. FH UNNES. Semarang.

Fakultas Hukum UNNES. 2010. Pedoman Penulisan Skripsi Fakultas Hukum. Semarang: Fakulatas Hukum UNNES.

Kurniawan, Agung. 2005. Transformasi Pelayanan Publik. Yogyakarta: Pembaharuan.

Kusumaatmadja, Mochtar. 2003. Pengantar Hukum Internasional. Bandung: Alumni.

Krustiyati, Atik. 2012. Kebijakan Penanganan Pengungsi Di Indonesia: Kajian Dari Konvensi Pengungsi Tahun 1951 Dan Protokol 1967. Vol 12, No.2 November 2012.

Moleong, Lexy J. 2009. Metode Penelitian Kualitatif. Bandung: Remaja Rosdakarya

Mulhadi. 2014. (Skripsi). Pelanggaran Hukum Nasional Indonesia yang dilakukan oleh pengungsi yang berada di Wilayah Indonesia. FH UNHAS. Makassar.

Romsan, Achmad. 2003. Pengantar Hukum Pengungsi Internasional: Hukum Internasional Dan Prinsip- 
Prinsip Perlindungan Internasional. Jakarta: UNHCR.

Said, M.Mas'ud. 2007. Birokrasi Di Negara Birokratis. Malang: UMM Press.

Setiawan, Hendra. 2013. Efektivitas Pengawasan Orang Asing pada Wilayah Kantor Imigrasi Kelas I Samarinda. Jurnal Ilmu Hukum. FH UNIBRAW: Malang.

Shofari, Bambang. 2000. Perencanaan dan Pengukuran Kinerja Organisasi. Jawa Tengah: BAPELKES.

Soekanto, Soerjono. 2011. Penelitian Hukum Normatif. Jakarta: PT RajaGrafindo Persada.

Tangkilisan, Hessel Nogi S. 2005. Manajemen Publik. Jakarta: Grafindo

Tribunnews.com. 2012. WNA Afganistan Merasa Tak Bebas. http://pontianak.tribunnews. com/2012/03/06/wna-afganistan-merasatak-bebas, diakses tanggal 30 Agustus 2014 jam 19.30 WIB

Ukun, Wahyudin. 2004. Deportasi Sebagai Instrumen Penegakan Hukum dan Kedaulatan Negara di Bidang Keimigrasian. Jakarta: AKA Press.

Wagiman. 2012. Hukum Pengungsi Internasional. Jakarta: Sinar Grafika.

Wilis, Ratna. 2009. (Tesis). Pengawasan dan Penindakan Keimigrasian Terhadap Izin Tinggal Orang Asing di Indonesia. FH USU. Medan.
Peraturan Perundang-undang:

Undang-Undang Dasar 1945

Undang-Undang Nomor 6 Tahun 2011 tentang Keimigrasian

Undang-Undang Nomor 39 Tahun 1999 tentang Hak Asasi Manusia

Undang-Undang Nomor 23 tahun 1992 tentang Kesehatan

Undang-Undang Nomor 11 tahun 2005 tentang Ratifikasi Kovenan Hak Ekonomi, Sosial dan Budaya

Peraturan Direktur Jendral Imigrasi Nomor IMI-1489. UM.08.05 Tahun 2010 tentang Penanganan Imigran Ilegal

Peraturan Direktur Jendral Imigrasi Nomor IMI.1917OT.02.01 Tahun 2013 tentang Standar Operasional Prosedur Rumah Detensi Imigrasi

Peraturan Menteri Hukum dan Hak Asasi Manusia Republik Indonesia Nomor M.05.IL.02.01 Tahun 2006 tentang Rumah Detensi Imigrasi

Keputusan Menteri Kehakiman dan Hak Asasi Manusia Republik Indonesia Nomor M.01-PR.07.04 Tahun 2004 tentang Organisasi dan Tata Kerja Rumah Detensi Imigrasi

Peraturan Diretur Jendral Imigrasi Nomor F-1002. PR.02.10 Tahun 2006 tentang Tata Cara Pendetensia Orang Asing 